Војо Ковачевић

https://doi.org/10.18485/ai_zsjoski.2018.1.12

Универзитет у Источном Сарајеву

821.163.41.09-3 Андрић И.

Филозофски факултет Пале

Катедра за српски језик и књижевност

\title{
НАРАТИВНИ ПОСТУПЦИ У ФУНКЦИЈИ КАРАКТЕРИЗАЦИЈЕ ЛИКОВА
}

У раду су истакнути наративни поступци и приповедачке перспективе којима се гради јединствен каталог књижевних ликова, нарави и карактера у Андрићевом прозном делу. Писац портретише личности разних народности, конфесија, положаја и занимања, а њихове природе и животне судбине су, у знатној мери, одређене земљом рођења или, пак, амбијентом у којем су одрасли и где живе. Књижевнокритички су сагледаване језичко-стилске вредности као и полисемичност његовог језичког израза, а са аспекта морфолошких, лексичких и семантичких особености језика, уочавамо аналогне везе на нивоу уметничког обликовања књижевних јунака. Критичка анализа утемељена је на вредновању језичког израза превасходно регионалног карактера, као и туђица, особито турског порекла, што доприноси „историчности” и посебности књижевних јунака у Андрићевом прозном делу.

Къучне речи: И. Андрић, књижевни јунаци, језик, стил, регионализми, турцизми.

Структура прозног дела Иве Андрића је, несумњиво, системски организована, инвентивно и прецизно творена, са препознатљивим ликовима који се јављају у различитим приповедним текстовима. Научнокритичком анализом фабуле, односно начином повезивања догађаја, 
потом анализом актера у раднь ${ }^{12}$, приповедних поступака и позичије наратора, уочава се комплексност прозног текста, функиионалност и полисемичност језичког израза. Семантички су обременени и фактура дела, интерпункцијски и ортографски знаци, али и белине текста, којима се сугеришу мисаоно-идејни и емотивно-психолошки садржаји и духовне перспективе.

Андрић у једном есеју тематизује генезу настанка литерарног дела, писиа пореди са градителем који пажльиво прикупьь материјале за остварене своје замисли, повезује блокове, глача саставке. У настојану да оствари органску целину, усаглашава сваки детаљ са местом и материјалом, обимом и обликом здања, а цео процес живо и контемплативно надгледа, од темеља до крова. Писац, пак, бира тему, издваја мотиве, уводи ликове, пребира по језику, али и низу других књижевних па и ванкњижевних елемената. И тако гради дело. Језик саображава са духом појединца и заједнице, националних и наднационалних оквира. Следи духовне хабитусе, мотивише њихове измене и језички их фиксира, свестан отворености семантичких поља и мена времена.

Из холистичке перспективе утемељене на анализи (су)односа мисаоних процеса и чулних перцепција, потом њихове духовне обраде, писац, при творби дела, настоји да превлада индивидуална ограничења и конвенцијом утврђене обрасце, универзализује литерарни свет и преведе га на метафизичку раван. Преплитања објективних чињеница и унутрашњих рефлексија одвијају ce перманентно: „Субјективна делатност образује у мишљењу неки објекат; ниједна врста представе не може се сматрати само прихватајућим посматрањем каквог већ присутног предмета. Делатност чула мора се синтетички

12 Објективно деловање актера је неразвијено и одступа од традиционалног реалистичког представљања и повезивања догађаја. 
повезивати с унутрашњом радњом духа, а из те везе истрже се представа, постаје објект, насупрот субјективној снази, и, као објект изнова опажена, враћа се у поменуту везу. Али за то је језик неопходан; јер будући да у њему духовна тежња утире себи пут кроз усне, њен производ се враћа њеном властитом уху. Дакле, представа се премешта у стварни објективитет, не одузимајући се субјективитету" (Хумболт 1988: 116).

Андрић, најчешће, на колоритан начин, истицањем одређених детаља, једном речју, или кратком реченицом, разумљивих некад само ужој заједници, напосе босанскохерцеговачком миљеу, активацијом одређеног језичког нивоа, саопштава дубље истине, поуке и опомене. Тако фра Петар, у позном добу, физички узет, али још увек „весео и румен у лицу”, сведочи како је, у младости, желео да оде из мрачног босанског вилајета и живи у неком од светлих европских градова, те, како је, након разговора са ћутљивим фра-Николом Гранићем, „ваљаним мештром младежи", јасно разабрао своје ондашње обмане и мучне недоумице. И фра Николино иницијално обраћање са „мој Јусуфе”, било му је сасвим довољно да схвати своје залуте: „И тад сам видео колико корисно и добро могу да говоре људи који умију да шуте” ( 19816: 150).

у питању је, свакако, наслеђени духовни обзор, препознатљиви садржаји и њихова именовања, којим се остварује објективизација унутрашњих представа, функционално натопљених експресивним језичким наносима и саображених са контекстуалним оквиром, као у назначеном примеру као специфичан вид комуникације. А турцизми које користе хришћани оба закона, у складу са одговарајућим говорним ситуацијама, значајно проширују семантичка поља и носе, не само комуникативну вредност, већ значајно доприносе карактеризацији ликова. Књижевни ликови сва три закона у одређеним говорним ситуација употребљавају многе туђице, 
примерице: дуњалук, хећим, араисалост, чардак, рахат и зенђил, сахаџијски, туфегџијски, сахат, душек, серџада, инсан, ајван, табијат и многе друге. Ти изрази, блиски њиховом духу, потврда су не само њиховог међусобног разумевана, већ одражавају и разнородне социолингвистичке и психолингвистичке аспекте.

Стилска маркираност језика сугерише значењска померања на нивоу приповедачких поступака, индиректног и директног казивања из перспективе наратора и појединих актера у прозном тексту. Као што смо истакли у уводном делу, фабуларни оквир у Андрићевој прози сведен је на најмању меру, скоро неприметан, а актери своју индивидуалност испољавају много више у специфичним говорним ситуацијама, нијансирањем њихових језичких исказа, него на основу својих поступака и природе догађаја. Често су њихови поступци супротни казивањима, а илустративан пример је католички свештеник самостана Крешево, Фра Марко Крнета, који се углавном бавио пословима око манастира и побожно водио мусафирхану ${ }^{13}$. Водећи непрестано тихи рат са Турцима и добро знавши њихову потребу да чине хришћанима свакојаки квар, при доласку три Турчина њима у походе, одмах се латио да сакрије пиће и намирнице. Како је један од те тројице Турака био болестан, чим дођоше траже лимунова, а „фра Марко се вајка: тражиће”, снисходљиво каже, „али се боји да неће бити”.

- Деде, погледај боље, немој да ја почнем тражити довикује Кезмо” 19816: 13).

13 „За турска времена, манастири су морали да уконачују Турке који би увраћали. Догађало се да би се понеки насилни Турци задржавали дуго у манастиру, пили и теревенчили. Да би очували прописан ред и тишину манастирску, фратри су обично поред манастира зидали једну повећу а одијељену собу за те госте. Она се звала мусафирхана" (Андрић 19816: 9). 
Пошто је фра Марко донео лимунове, он заповеда друго: „Е, сад скини таву да објесим пушку - шали се Кезмо. Фра Марко скида таву и почиње да спрема кајгану" (19816: 13).

На разини приповедачких поступака ${ }^{14}$ уочљиво је да су врло блиски позиција наратора, која се остварује у трећем лицу, Er-Form, и персонални говори актера у причама. Такав однос је остварен и на нивоу наративних перспектива, јер Андрићев наратор је, несумњиво, свезнајући, а то се препознаје не само на нивоу структуре приче, већ и на нивоу, слободно можемо рећи, целокупног његовог прозног опуса. Поједини књижевни ликови граде приповедне циклусе - фра Марко, Алија Ђерзелез, али се јављају и у делима различитог жанровског карактера - фра Петар у приповеткама и роману. Дакле, наратор и актери у прозном делу, у погледу лексичких исказа, тесно су повезани, чиме се карактеризација или индивидуализација ликова остварује и са позиције казивања и наратора и актера „догађања”. Лексичка подударност се остварује, пре свега, функционалном синхронизацијом употребе турцизама или дијалектизама у персоналном и имперсоналном говору. Поред тога и развијени дескриптивни пасажи које твори наратор, као и стилизација одређених делова радње или, пак, стилизација поступака њених актера, доприносе њиховој потпунијој карактеризацији и индивидуализацији.

У приповеци У зиндану писац осветљава карактере личности трију конфесија као и њихове положаје и прилике у којим делају. Након везировог опозива у Стамбол, власт је задобио ћехаја Фазло, који, добро изучивши методологију отоманске власти, жури да покупи што више пореза до наименовања новог везира. Шаље своје

14 Види: Mike Bal, Naratologija - teorija priče i pripovedanja, prevela: Rastislava Mirković, Narodna knjiga - Alfa, Beograd. 
војнике у посету манастирима и захтева да њихова преосвештена лица дођу у Травник. Разумевши позив, старешине оба закона, отпослаше фра Марка и зеничког проту, у нади да ћехаја Фазло прихватити њихов поклон. Али, незадовољан њиховим даровима, обневидео од беса, Турчин својим сеизима наређује да их затворе и муче. Делећи исту муку, зенички прото, саветује фра Марка како да ублажи њихово заједничко зло. Говори му да својој братији, истог трена, напише писмо, што он и чини: „Ево ме Фазло метно у зиндан. И воду су подлили под мене. Mitte statim per hunc Turcam duos aureos, ut adminus istam aquam preniciosissimam intromittere desinant. Orate pro me et benedicite. ${ }^{15}$ И избављајте ме код Фазле, јер погибох".

фра Марко, викар”

Употреба различитих језичких идиома недвојбено указује на односе поробљивача и заточених, осветљава њихов положај, обест, опрезност и страх. Разумевање поробљених остварује се без речи, тишином, али и смехом који има вишеструко значење, јер делећи га са другима, он блажи тугу, а смех на свој „рачун”, богати и јача дух. Ћутња постаје речитија од говора, док гест и мимика попримају врло зорну комуникативну функцију. Весело светлуцање смеха истодобно рефлектује и властиту горчину: „Одједном се фра-Марку учини као да је прото нешто рекао. Застаде и ослухну: изгледало је као да пригушено кашље, али што је дуже слушао све му се чуднији чинио тај кашаљ, док се из друге ћелије јасно не разлеже старачки смијех. Фра Марко се љутну, испрси и заусти нешто да рекне, али је смијех бивао све живљи и гласнији.

„Ох, о,о, фра Марко.

15 Пошаљи одмах по овом Турчину два дуката, да бар ову страховиту воду зауставе. Молите се за мене, и благословите. 
Шта је, шта се смијеш”- питао је фра Марко набусито. [...] „Смијем се ... како нас је Фазло опет лијепо саставио ... ox, ox, хоо... Ето вас, каже, у зиндану па се препирите: ко ће бир по Босни купити. И још воду подли под нас. Ox, ox, xoo!"

И фра Марко се даде на смијех.

„Вала нас је покиселио ко у туршију”.

„Да се види чија је вјера тврђа”.

„Ax, xa, xa, xaа ...”

„Xo, xo, xo, xooo”.

На основу апострофираног прозног исечка, уочавамо обележја модерног приповедача и модерне уметности, супротно традиционалистима и „класичним” списатељима/уметницима. Наведени пример пластично изражава назначена својства и прецизно означава њихову дистинкцију. Естетски диферентни знакови на нивоу традиционално/модерно, односно класично/модерно, деле се у две групе: знак од нечега и знак о нечему. „Знак $o$... је према томе ознака за неко друго биће (репрезентација), а знак од ... је проговарање самог бића (презентација). [...] Док је класична уметност била субјективни одраз објективне стварности, новију бисмо могли назвати објективним одразом субјективне стварности, објективирањем субјективности" (Фохт 1959: 118-119).

Чујна полифункционалност разгласавања смеха, као знака о нечему или некому што се разлеже унутар затвореног простора, упућује на разнородна сематичка поља, и на жив, акустичан начин објективизују њихова унутрашња стања и особне субјективитете. Дакле, писац истиче индивидуалне и националне посебности које су у језик уроњене, и у њему се испољавају емотивно-ментални и психолошко-интуитивни садржаји. Рафинираност или сиромаштво, односно порозност духа, језиком су опточени. Језик најдубље памти и време другим аршинима мери. Семантика његова, иако често бледи, никада 
не нестаје, док значењски рефлекси, попут понорница, и мимо уобичајених мерила, с времена на време, цело биће плаве. Јер језик, посигурно, поуздано сведочи о личним, националним и наднационалним специфичностима, времену и простору.

У Андрићевој прози живо су дочаране разлике и сличности међу људима који обитавају на истом простору и у истој заједници, као и о људима различитих народности и вероиспосвести. Истичући супротности између исмаилћана и хришћана, фра-Петар у краткој причи Труn колоритно описује суровог Челеби Хафиза који је цијелу Сирију спржио. И поклонивши живот младој Сиријки, Челеби-Хафиз најпосле остаде осакаћен. Комадајући га све до трупа, изведе правду, из освете, она што је заволе: „Коло је водила та иста најмилија жена Челеби-Хафиза, Сиријанка. Она је ово годинама смишљала и спремала, вјешто се претварајући и чекајући згодан тренутак да своју освету изврши. И док је имао очи да гледа, могао је да види: најдраже од свих бића, једино створење над којим се сажалио, које му је било блиско и коме је у животу повјеровао, скакало је око њега, избезумњено и запјењено, и добацивало му нејасне ријечи и увреде. Она није дала да га убију, а њу су сви слушали, јер је хтјела да га гледа како се мучи, и да он види да га она гледа. Пребили су му руке испод лаката и ноге испод кољена и ударали су га запаљеним машалама" (1981: 114).

Посматрајући кретње обогаљеног силника, Фра-Петар, сведок многих зулума и бестијалних радњи, обесних мучења и свирепих убистава, Челеби-Хафизове браће по вери, у Босни, над хришћанским живљем оба закона, са горчином констатује: „Јесте, такав је Турчин. Исјеци га на комаде, сваки комад тијела му живи за себе. И посљедњи драм меса миче се исто онако и гамиже у истом правцу у ком би се жив и читав Турчин кретао. А крштен човјек је као срча: куцнеш га на једно мјесто, а он прсне у комаде, и нема му лијека ни поправка" (1981: 117). 
Андрић нијансирањем језичког знака, дескриптивним или наративним поступцима, карактерише ликове, док ванредним наратолошким умећем: функционалном фабулом, сижејном основом или укрштањем приповедачких поступака - „плете” приче у којима се срећу и сударају разнородна лица. Сложеност тих односа осветљава изнутра, не у линеарном протоку времена, већ ослањањем на тврде белеге из прошлости. Такво перципирање времена, издваја се као свеприсутан, главни лик у многим причама о људима и њиховим наравима. Пословичност исказа које срећемо у Андрићевој прози израз су искуствених сазнања не само појединаца, већ и главе цела народа: „Ено бегови у меџлису вијећају, а нису војске купили ни с господом вијећали. А, ко жив буде, видјеће и њихово. Алакнуће два-трипут, истурит који фишек, па ће трчати кући да их жена закључа у магазу. А нек Швабо остане само три године у Сарајеву, они ће први натући шапке на главу, и отимати се за швапске крстове, и залагати крметином. Е, мој ваљани Велипашо, нема овдје више човјека, него гладна фукара, и још гладнији бегови. Свачије ће ово још бити, а наше, бели, што је било - било" (1881a: 121)

Антагонизми којима су, као у пауковој мрежи, премрежени људи у тематизованим заједницама, само се покаткад превазиђу, изнимно бришу и заборављају, а хумани и уљуђени односи, готово по правилу, извргавају руглу и злоупотребљавају. Склад и лепота се на овом уском хоризонту уз велику жртву откупљују. Стога су жалосне речи фра-Николе Гранића о Босни и њеним људима: „[...] Ово је земља оскудна и убога, тијесна и мрка, ни валија није у њој лако бити а камоли раја и редовник. У овој се земљи једна чаша види и боде очи као највиша кула у некој другој. Коме је до тога да буде рахат и зенђил, није му се требало у њој родити ни зафратрити. Овдје се драм радости душом плаћа" (1981: 149). 
Критичком анализом књижевних ликова уочавамо разноврстан каталог њихових нарави и карактера. Уочљива су, као што смо истакли, њихова груписања на више нивоа: конфесионалном, сталешком, регионалном и родном, а заједнички именитељ им је чврста везаност за босанскохерцеговачки хум. И на тој тврдој земљи, неки теку своје године из нужде, по казни, а неки по животном усуду, рођењем. У Андрићевој прози уверљиво су дочаране њихове животне судбине, доживљаји, размишљања и преживљавања. Издвојићемо личности који припадају различитим конфесионалним заједницама, те, следствено томе, критички сагледавати њихов карактер мисаоно-емотивни склоп и психолошки профил. Видне су разлике, али и сличности, у менталитету римокатолика, православаца и мухамеданаца. Писац ьихове особености сагледава из различитих перспектива, указујући на друштвено-историјски оквир, регионалне и географске специфичности, али и детерминишући социјалне и културолошке ознаке.

Са аспекта антропогеографије успоставља комплементаран однос на разини природе, односно рељефа и човека. Печат босанскога тла, као у искривљеном огледалу, осликава се на Андрићевим јунацима, карактер им бруси и душу ваја: „Затворен видик, мршава земља, дивља клима, честе похаре и ратови, давали су већ дјеци касаблијски изглед, борбен и манијачки. Кад би младић дорастао, оженио се, стекао дјецу и навршио двадесет пету годину, он је већ био оборужан за живот у касаби и завршен као тип: мрк, погнут, жилав, оштра жмиркава погледа, послован, понајвише ћутљив и забринут" (1981а: 172).

Њихови карактери су сенчени честим сукобима, љубавима и мржњама, неповерењем и страховима. Назначена својства изражена су код посрнулог беговата, у време дуготрајне агоније њиховог Царства. Њихову судбину верно одражавају животи браће Морића, код 
којих истодобно егзистирају мизантропска обележја и мазохистички пориви, прекомерна саможивост и сирова охолост. Контемплативно развијајући узроке који утичу на особите карактере људи и њихове рефлексе, у Знаковима (1981г: 201), на појединим местима, оцртава примарно ментално устројство својих сународника: „У нас је чест тип човека који мисли да је свађа акција, а грубост исто што и енергија, да нанети непријатељу увреде значи што и задати му ударац, да је свака уздржљивост у говору слабост, а сваки покушај предвиђања - дангуба; укратко: да се тзв. животна борба састоји од непрестаног и наизменичног лавежа и режања".

Такође, у детаљно развијеним дескриптивним описима, колоритно осликава физичке особености својих књижевних ликова, а потом их самерава, не само са њиховим карактерима, већ и са генеолошким стаблом, друштвеним амбијентом и историјским приликама. Живописни портрети откривају разне судбине, јер се унутрашњи живот, психолошке и емотивне замршености рефлектују у чулно оспољеним изразима: на лицу, у гласу, покрету или погледу. Као на сликарским платнима слика црте лица, очи, нос, боре што сведочи не само о њиховим тегобним животима, већ и необузданим страстима. Неухватљиве линије којима су премрежена лица, налик су грубо узораним браздама што се у млазевима сливају од чела до браде, и пониру у врат и груди. Писац, такође, врло пластично дочарава, обичном посматрачу једва приметне рефлексе душе, попут даха или уздаха, осмеха, блеска у оку и дрхтаја тела: „Тог јесењег дана Гага је нешто унела и одмах кренула ка вратима, са таласом нових димија који је изгледао као да је носи.

- Стани! - викнуо је неочекивано и промукло газда Јеврем. Стала је, окренула се, и погледала га право у очи. Поглед јој је био несигуран, замагљен и влажан, негде у дну као насмејан. 
Гледао је неколико тренутака у њу. На лицу му се није ништа могло приметити, али - незампамћена ствар! - газда Јеврем је у себи био изненађен, уплашен, могло би се рећи, кад би било могуће да се и он нечега уплаши" (19816: 98).

Човеково непознавање света и односа у њему, али и властите природе, блиске су Блез Паскаловим Mucлима о човековој природи, будући да „његово срце има своја умовања које ум не познаје”, на шта указује Јелена Новаковић (2001: 46), самеравајући Андрићеву прозу са делима значајних француских писаца. Обрт који се десио у газда Јевремовом животу, уз снажан унутрашњи потрес његове душе, изазван Гагиним младалачким расцветавањем, додатно је развио Андрић у Знаковима поред nyma: „Велике снаге, које ми волимо да називамо 'слепим' дејствују у просторима око нас, сударају се, ломе и губе. Оне живе и раде у нама, носе нас, витлају, уз учешће свести или без ње” (1981г: 178).

Одмерени и стамени ликови, чини се исклесани из чврстог гранитног комада, без иједне жиле и пукотине, самољубљиви и недодирљиви, који вешто и мудро скривају своје намере, одговарају, такође, наводи Новаковић (2001: 47), Паскаловим констатацијама о подвојености човековог бића: „Човек је, дакле, само дволичност, само лаж и лицемерство, и сам собом и према другима”. Потврда таквог мишљења је и назначени Андрићев јунак, а имајући у виду да су дела француских писаца попут Паскала, Ла Рошфукоа, Монтења, Стендала, Мопасана и других били његова омиљена лектира, о чему сведочи и сам писац у својим исписима и белешкама, могуће је утврдити и низ других аналогија. ${ }^{16}$ И на другим местима у прозном тексту Иве Андрића, назначена су разноврсна размишљања о човеку, природи, пределима или карак-

16 Види: Јелена Новаковић, Иво Андрић и франиуска книжевност, Филолошки Факултет : Народна књига, Београд, 2001. 
терима. Слично Паскаловим размишљањима о човеку и Андрић суди: „Нема те способности ни те добре особине коју ми не бисмо желели да припишемо себи; само што ту жељу у нама ућуткава контрола разума, али ограничени и једноставни људи не умеју да је сакрију, него говоре о њој отворено и јавно се брукају и чине смешним” или, пак, закључује: „Готово сваки живи човек носи своју тајну” [...] И кад бисмо умели тумачити израз људског лица, стварни а не скривени смисао човекових речи и покрета, открили бисмо доста чудесно лепих и невероватно страшних ствари о којима наша мудрост и не слути, о којима никад не говоримо или не пишемо. И знали бисмо више, бар нешто више, него што знамо о човеку и његовим путевима и беспућима" (1981г: 165$166,172)$.

Андрић (1981г: 171) уочава и посведочује блискост, али, у одређеним ситуацијама, и подударност својих мисли са мислима других узвишених духова: „Признаћу без оклевања: не волим много оне који воле много да питају, а онима који су ми пријатељи казујем, често и непитан, све што желе да знају о мени, мојим мислима, плановима и пословима, као и осећањима која их прате (Накнадно сам нашао сличну мисао св. Августина: „Si, nemo ex me querat, scio; si querenti explicareних velcim, nescio")”.

Тематизујући необичне карактере и онеобичаванем стварносних догађаја и радњи, Андрић осветљава архетипски основ којим је премрежен свет књижевности. У Разговору са Гојом (1981д: 20) наводи: „Али сваки умјетник који хоће да слика оно што сам ја сликао присиљен је да покаже покрет који је збир свих тих многобројних покрета, а тај згуснути покрет нужно и неминовно носи на себи печат истинског порекла, напада и одбране, беса и страха. Ето зашто су моји ликови и њихови ставови и покрети мрки, често страшни и језиви. Зато што, у ствари, друкчијих покрета и нема". 
Галерија Андрићевих књижевних ликова, нарави и карактера представља ванредно обликован орнамент на носећим стубовима чврсто изграђене архитектонике његовог прозног дела.

\section{Литература}

Андрић 1981: Иво Андрић, На Дрини ћуприја, Сабрана дела, књ. 1, Удружени издавачи: Просвета, Београд; Младост, Загреб; Свјетлост, Сарајево; Државна заложба Словеније, Љубљана, Мисла, Скопје, Побједа, Титоград.

Андрић 1981а: Иво Андрић, Немирна година, Сабрана дела, књ. 5, Удружени издавачи: Просвета, Београд; Младост, Загреб; Свјетлост, Сарајево; Државна заложба Словеније, Љубљана, Мисла, Скопје, Побједа, Титоград.

Андрић 1981б: Иво, Андрић, Жеђ, Сабрана дела, књ. 6, Удружени издавачи: Просвета, Београд; Младост, Загреб; Свјетлост, Сарајево; Државна заложба Словеније, Љубљана, Мисла, Скопје, Побједа, Титоград.

Андрић 1981в: Иво Андрић, Историја и легенда, Сабрана дела, књ. 12, Удружени издавачи: Просвета, Београд; Младост, Загреб; Свјетлост, Сарајево; Државна заложба Словеније, Љубљана, Мисла, Скопје, Побједа, Титоград.

Андрић 1981г: Иво Андрић, Знакови поред пута, Сабрана дела, књ. 16, допуњено издање, Удружени издавачи: Просвета, Београд; Младост, Загреб; Свјетлост, Сарајево; Државна заложба Словеније, Љубљана, Мисла, Скопје, Побједа, Титоград.

Андрић 1981д: Иво Андрић, Историја и легенда, Сабрана дела, књ. 12, Удружени издавачи: Просвета, Београд; Младост, Загреб; Свјетлост, Сарајево; Државна заложба Словеније, Љубљана, Мисла, Скопје, Побједа, Титоград.

Бал 2000: Mike Bal, Naratologija - teorija priče i pripovedanja, prevela: Rastislava Mirković, Narodna knjiga - Alfa, Beograd. Хумболт 1988: Vilhelm fon Humbolt, Uvod u delo o Kavi jeziku; $i$ drugi ogledi, Književna zajednica Novog Sada; NIŠRO Dnevnik, Novi Sad. 
Фохт 1959: Ivan Focht, Istina i biće umjetnosti, Svjetlost, Sarajevo. Новаковић 2001: Јелена Новаковић, Иво Андрић и француска книжевност, Филолошки Факултет : Народна књига, Београд.

Vojo Kovačević

\section{NARRATIVE PROCEDURES IN THE FUNCTION OF CHARACTER CHARACTERISATION}

Literary characters in the prose of Ivo Andric beside the emphasized individual lines contain the features of an archetypal character. Their complexity the writer illuminates from different perspectives, their psycho-emotional personality and psychological states cross or, in any event, communicate with historical, geographical, genealogical or rational features. By the functional use of various narrative processes and narrative perspectives, the writer illuminates their individual characteristics, nature and characters. The author colorfully portrays literary characters by bringing them into direct relationships that are shadowed by conflicts, love and hatred, mistrust and fears. By tematizing these unusual characters and ignoring the actual events and actions, Andrić simultaneously illuminates the archetypal basis that crosses his prose text.

Key words: I. Andrić, literary heroes, language, style, regionalism, Turkism 